\title{
The Female Reproductive System of Zearaja chilensis (Guichenot, 1848) (Chondrichthyes, Rajidae). Gametogenesis and Microscopic Validation of Maturity Criteria
}

\author{
El Sistema Reproductor Femenino de Zearaja chilensis (Guichenot, 1848) (Chondrichthyes, \\ Rajidae). Gametogénesis y Validación Microscópica de los Criterios de Madurez
}

Anahí Wehitt"; Edgardo E. Di Giacomo**,*** \& Elena J. Galíndez,***

WEHITT, A.; DI GIACOMO, E. E. \& GALÍNDEZ, E. J. The female reproductive system of Zearaja chilensis (Guichenot, 1848) (Chondrichthyes, Rajidae). Gametogenesis and microscopic validation of maturity criteria. Int. J. Morphol., 33(1):309-317, 2015.

SUMMARY: Chondrichthyans are extremely susceptible to overfishing due, among other things, to their reproductive adaptations. Basic knowledge of reproductive parameters is essential, both of ecological and for economic points of view. Zearaja chilensis is a valuable economic resource in South America. This work analyzes the microanatomy of female reproductive system, as well as the size of the onset of vitellogenesis. The material was fixed in Bouin and processed using routine histological techniques. Both ovaries are equally functional. Folliculogenesis depicts the same pattern of other Chondrichthyans. Follicles with different degrees of maturation coexist in mature animals, with the exception of oogonia, which were only found in immature individuals. Likewise, atretic follicles were recorded in all stages of maturation. The size of yolk input, microscopically recorded, is lower than the detected at naked eye. Oviductal glands and uterus show similarity with those reported in other lecitotrophic cartilaginous fish. This work reports, for the first time, the morfofunctional microanatomy of the species, and puts to the test the accuracy of the commonly employed criteria for the determination of sexual maturity, a critical data when determining management policies.

KEY WORDS: Elasmobranchs; Reproductive system; Ovary; Zearaja chilensis.

\section{INTRODUCCIÓN}

Chondrichthyans are considered one of the most successful groups of animals from the evolutionary standpoint. These fish have adapted effectively over eons, resulting in a great diversity of species of rays, skates, sharks and chimeras. Their reproductive strategies, among other aspects of their life history, have made them highly susceptible to exploitation (Musick \& Ellis, 2005). In the last years, the interest of fisheries worldwide has focused increasingly in elasmobranchs. This combination of factors has put these fish in a complicated situation, either from the conservational point of view as the economic (Dulvy et al., 2008). In Argentina, batoids are the most representative group of Chondrichthyans within the catches (Massa \& Hozbor, 2011). This is an important topic, if we take into account that skates and rays are the most vulnerable group among cartilaginous fish, to overexploitation (Duvly \& Reynolds, 2002).
The "red skate" Zearaja chilensis is an oviparous skate attaining about $120 \mathrm{~cm}$ in total length. Because of its large size, is highly appreciated by the fishing industry. $Z$. chilensis has been historically captured as by-catch (Rivera Gómez \& Pettovelo, 2000) but, since 1999 it has become the target of directed fishery. Massa \& Hozbor, have reported a decrease in the abundance of this species in the period between 1993 and 2005. As a result of this, Z. chilensis is considered by the IUCN Red List as "vulnerable, A4bd" (Kyne \& Simpfendorfer, 2007).

Worldwide, most countries have implemented programs with a multidisciplinary approach, designed to address studies of the life history of commercially important Chondrichthyan species. Indeed, the importance of morphologic analysis on reproductive cycles has been recognized (Alonso Fernández et al., 2011) and it has proven to be a useful tool as it provides

* Laboratorio de Histología Animal, Departamento de Biología, Bioquímica y Farmacia, Universidad Nacional del Sur, Buenos Aires, Argentina.

** Instituto de Biología Marina y Pesquera "Alte. Storni” (CONDROS).

*** Universidad Nacional del Comahue, Buenos Aires, Argentina.

***** INBIOSUR-CONICET.

This work was supported by the SGCyT-UNS, PGI 24/B173. 
accurate information of reproductive parameters, needed for drawing up conservation polices.

The aforementioned being considered the aim of this paper is to analyze the microscopic anatomy of the female's reproductive system of $Z$. chilensis and to verify the accuracy of the macroscopic maturity criteria employed in the species.

\section{MATERIAL AND METHOD}

Females were collected from landings of the commercial fleet operating in the San Matías Gulf (41 $42^{\circ}$ $42^{\circ} 41^{\prime} \mathrm{S} ; 63^{\circ} 45^{\prime}-65^{\circ} 09^{\prime} \mathrm{W}$ ). Measurements of the total length, disc width and weight of each specimen were recorded. Sexual maturity was determined by direct observation of ovaries according to Serra-Pereira et al. (2011). Small pieces of the ovaries, oviductal glands and uteri were fixed in Bouin mixture in seawater. The material was embedded in Paraplast ${ }^{\circledR}$, cut at $5 \mu \mathrm{m}$ and stained with hematoxylin-eosin and Masson's trichromic stain for general observations. The periodic acid Schiff reaction and the Alcian blue technique at $2.5 \mathrm{pH}$ level were employed to analyze the glycoproteins distribution. The Sudan Black technique was used to dye vitelline precursors.

\section{RESULTS}

The genital system of $Z$. chilensis comprises two similarly sized ovaries, one ostium, two oviducts, two oviductal glands, two uteri and one urogenital sinus.

Ovary: Ovaries are similarly sized, elongated, dorsoventrally compressed organs, associated to the lymphomyeloid tissue known as the "epigonal organ" (Fig. 1). As ovarian maturation proceeds, the epigonal organ retracts to the caudal zone. This maturity wave occurs from cranial to caudal and from ventral to dorsal. The organ is surrounded by a simple columnar and ciliated epithelium that lies on a thin and vascularized connective tissue. The surface is folded and the epithelium acquires a pseudostratified aspect (Fig. 1). As follicles increase in number and size, the ovarian epithelium stretches. Follicles internalize according maturation progresses.

The ovarian parenchyma comprises oogonia and follicles in different stages of development (primordial, primary, developing, vitellated and atretic), all of them immersed in a loose connective tissue network. Diameter of different structures is shown in Figure 2.

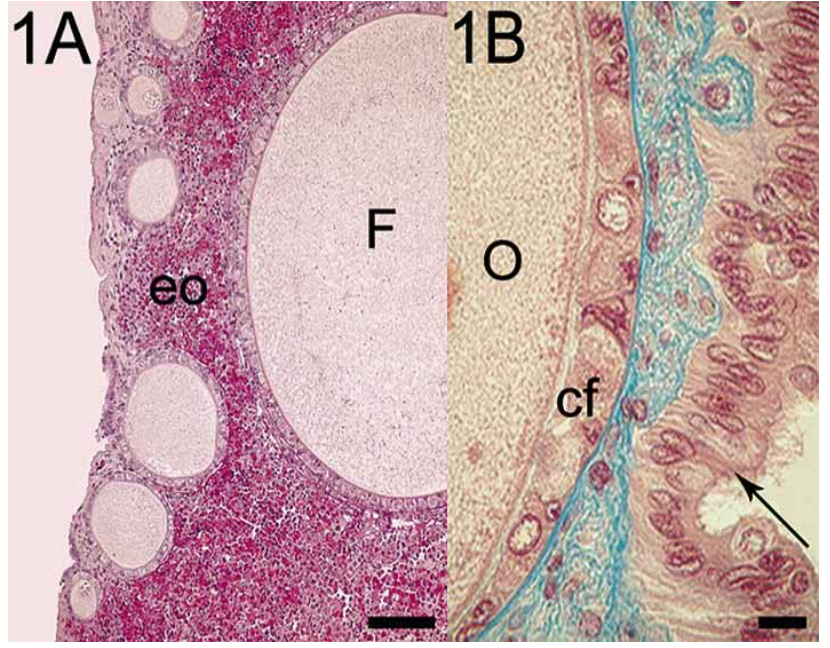

Fig. 1. A. General view of the ovary of a sexually immature female. $\mathrm{F}=$ follicle; eo= epigonal organ. Hematoxiline-eosine. Scale bar: $160 \mu \mathrm{m}$. B. Ovarian wall. Arrow indicates the folded germinative epithelium; $c f=$ follicular cells; $o=$ oocyte. Masson's Trichromic stain. Scale bar: $20 \mu \mathrm{m}$.

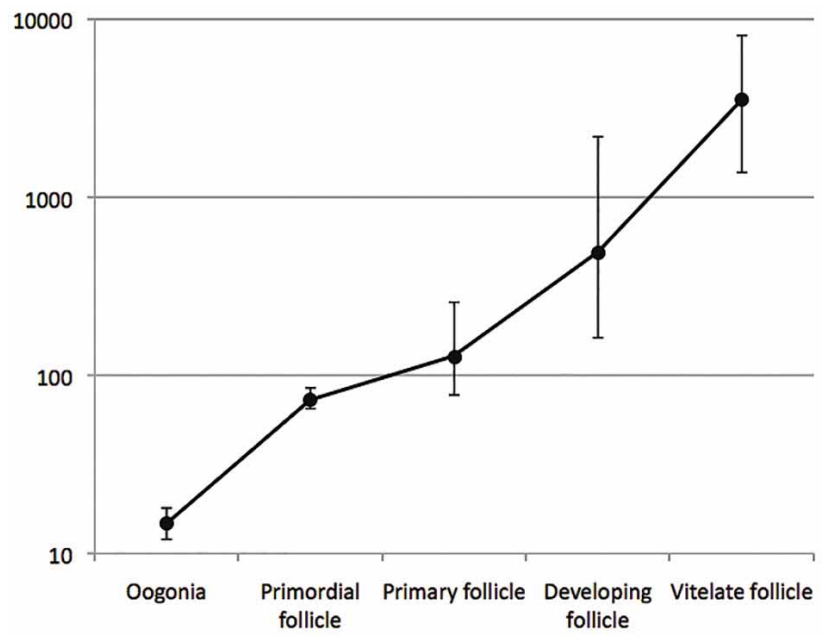

Fig. 2. Diameter of oogonia and follicles. Note that, since the beginning of meiosis, growth seems to be more widespread and appears to be slightly lower speed. However, there is insufficient information to statistically compare the slopes. Ordinate is in logarithmic scale.

Oogonia are characterized by their high nucleus: cytoplasm ratio. The nucleus is typically centric and euchromatic and the cytoplasm is slightly basophilic (Fig. $3)$. This cell type was found only in one sexually immature animal.

Follicles form when the oogonium associates with follicular cells. In the primordial one, the oocyte is surrounded by a monolayer of follicular squamous cells (Fig. 


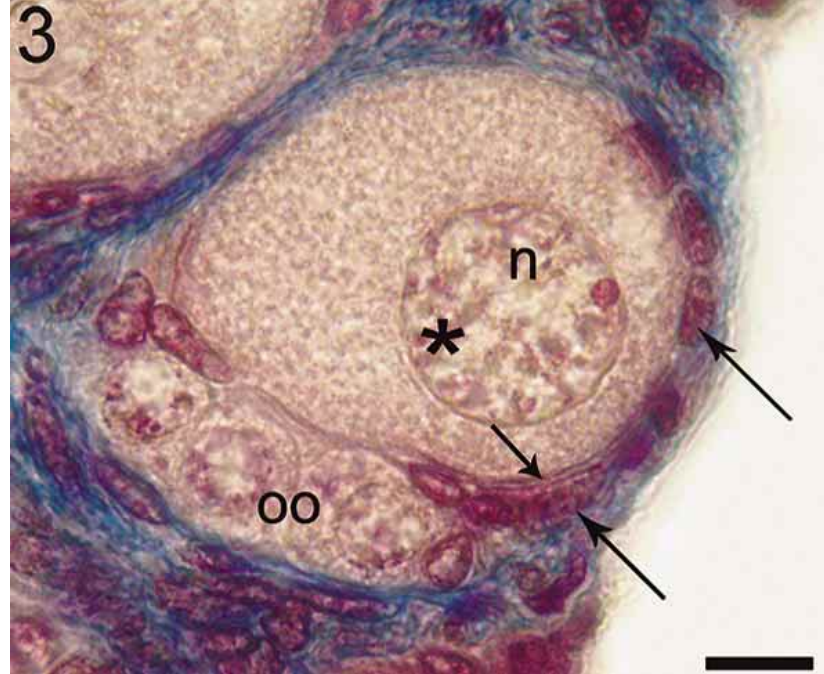

Fig. 3. Oogonia and primordial follicle formation. Note the flat simple follicular epithelium (large arrows) and the incipient zona pellucida (short arrow). Asterisk indicates the "lampbrush chromosomes"; n= nucleus; oo= oogonia. Masson's Trichromic stain. Scale bar: $10 \mu \mathrm{m}$.

3). The germinal nucleus is euchromatic with heterochromatin clumps ("lampbrush chromosomes", Fig. $3)$. PAS reaction foregrounds the early deposit of glycoprotein patches between the oolema and follicular cells. Primary follicles characterize by a simple stratum of highly basophilic follicular cells, both cubic and columnar (Fig. 4). Interspersed between them, there are few globed-shaped cells with a slightly basophilic cytoplasm and a round euchromatic nucleus (Fig. 4). The oolema is densely folded and looks as a refractive line (Fig. 4). The zona pellucida is well defined and surrounds the entire oocyte (Fig. 4). This zone stains positively with PAS but there is no reaction to the $\mathrm{AB}$ technique.

According maturation progress, the follicle increases in size, the zona pellucida thickens and the thecas differentiate into an inner one, formed by eosinophilic squamous cells and an outer, comprising one or two layer of squamous basophilic cells (Fig. 5A).

The progression of the follicular maturation process implies the increase in thickness of the zona pellucida, the stratification of the follicular envelope and the formation of a vascular network between thecas (Fig. 5A). The follicular epithelium depicts two cellular types: the columnar eosinophilic cells and the globed-shaped ones. The latter show a basophilic cytoplasm and granules that stain with Sudan B (Fig. 5A). Granulosa cells and oolema interact through thin projections running through the zona pellucida (Fig. 5B).

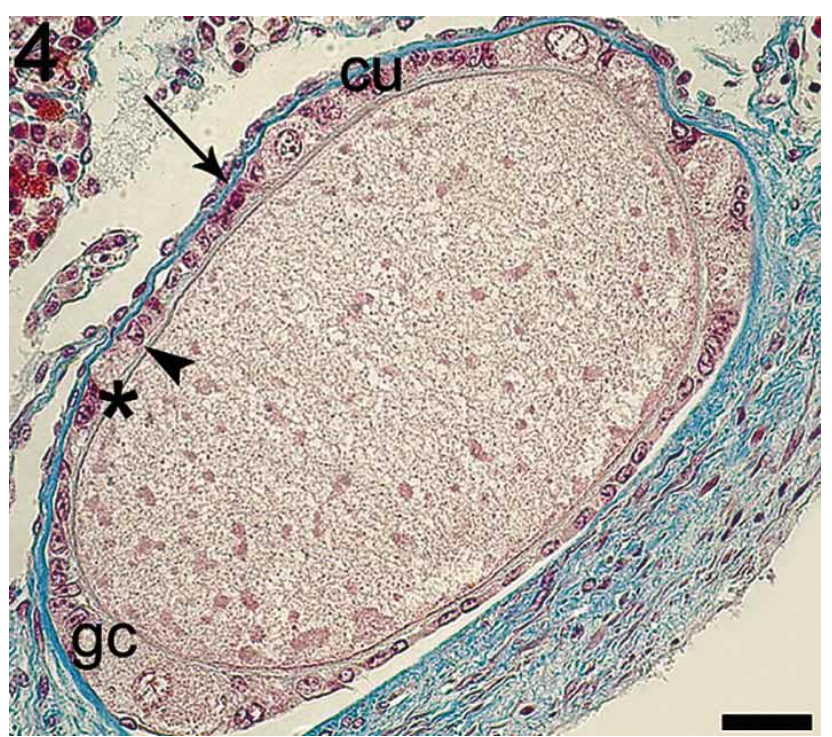

Fig. 4. Primary follicle. Arrow head depicts the folded oolema abutting against the zona pellucida (asterisk); arrow depicts the theca; $c u=$ cubic cells; gc= globed-shaped cells. Masson's Trichromic stain. Scale bar: $30 \mu \mathrm{m}$.

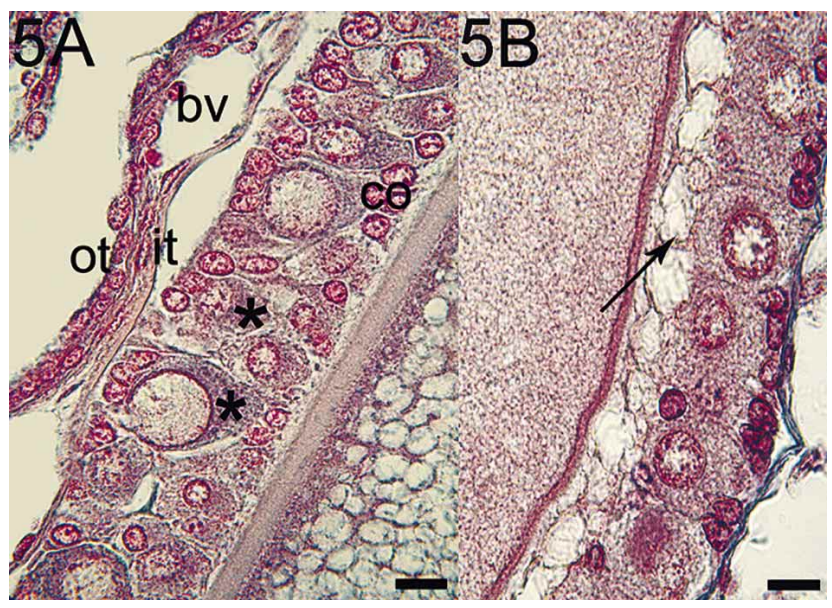

Fig. 5. A. High magnification image of a stratified follicular epithelium. Note the cytoplasmic stain affinity of globed-shaped cells (asterisk); $c 0=$ columnar cells; $b v=$ blood vessel; it $=$ inner theca; ot= outer theca. Sudan Black stain. Scale bar: $15 \mu \mathrm{m}$. B. Arrow indicates the thin projections of the follicular cells. Masson's Trichromic stain. Scale bar: $15 \mu \mathrm{m}$.

Yolk accumulation occurs in a centripetal pattern (Fig. 6). Initially, small acidophilic granules appear underneath the plasmalema. Then, granules coalesce to form elliptic plates (Fig. 6). Microscopically, the yolk input begins when follicle attain about 1400 micrometer. Nevertheless, the macroscopic evidence of yolk accumulation (yellowish coloration) appears when follicles are up to $1.2 \mathrm{~cm}$. The largest follicular diameter recorded was of $5.2 \mathrm{~cm}$. 


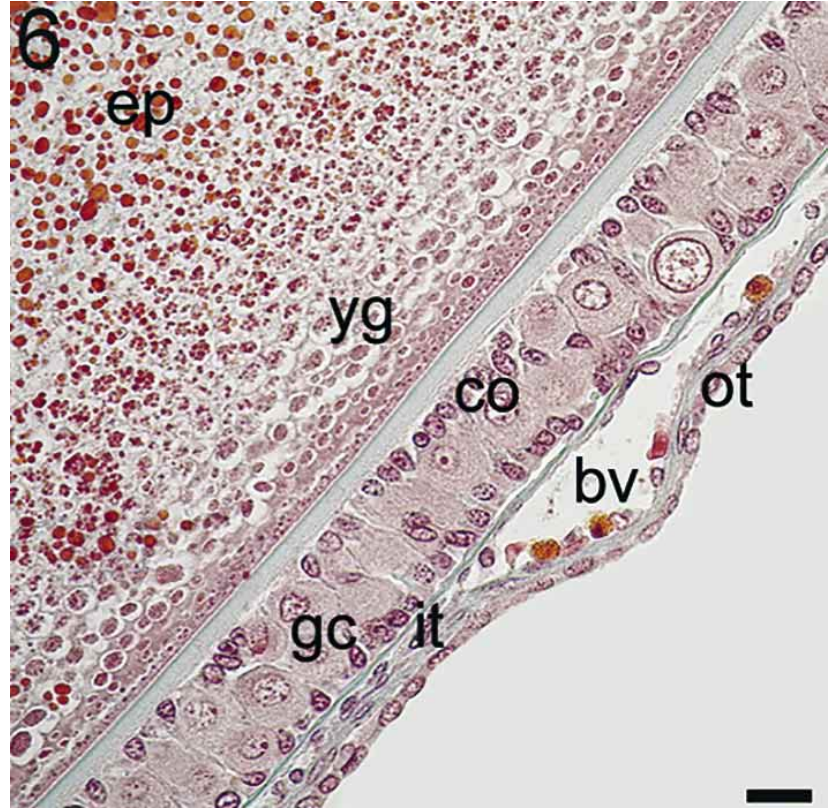

Fig. 6. Vitellating follicle; bv= blood vessel; co: columnar cells; ep= elliptic plate; $\mathrm{gc}=$ globed-shaped cells; $\mathrm{it}=$ inner theca; $\mathrm{ot}=$ outer theca; yg= yolk granules. Masson's Trichromic stain. Scale bar: $30 \mu \mathrm{m}$.

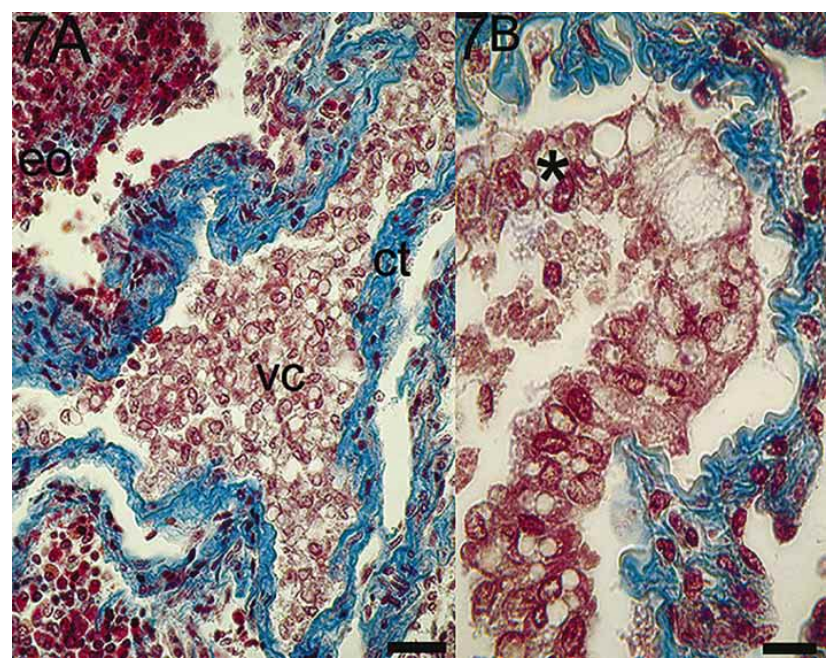

Fig. 7. A. General view of a recent forming atretic body; ct= connective tissue; eo= epigonal organ; $\mathrm{vc}=$ vacuolated cells. Masson's Trichromic stain. Scale bar: $35 \mu \mathrm{m}$. B. Vacuolated follicular cells (asterisk). Masson's Trichromic stain. Bar $25 \mu \mathrm{m}$.
Atretic bodies were present in all studied fish. As the oocyte retracts, the follicular cells collapse. At the beginning of the process, follicular cells vacuolated and show clear evidences of apoptosis (Fig. 7). Finally, the connective tissue infiltrates the area, forming a scare-like structure (Fig. 7).

No evidence of corpora lutea was found.

Oviductal gland: The oviductal gland comprises a set of tubular glands, arranged in different zones according their morphology and dye affinity (Figs. 8-10). The lumen is coated by a simple columnar ciliated epithelium. Adenomers contain columnar ciliated supporting cells and glandular cells. Based on the nature of the secretion, it is possible to

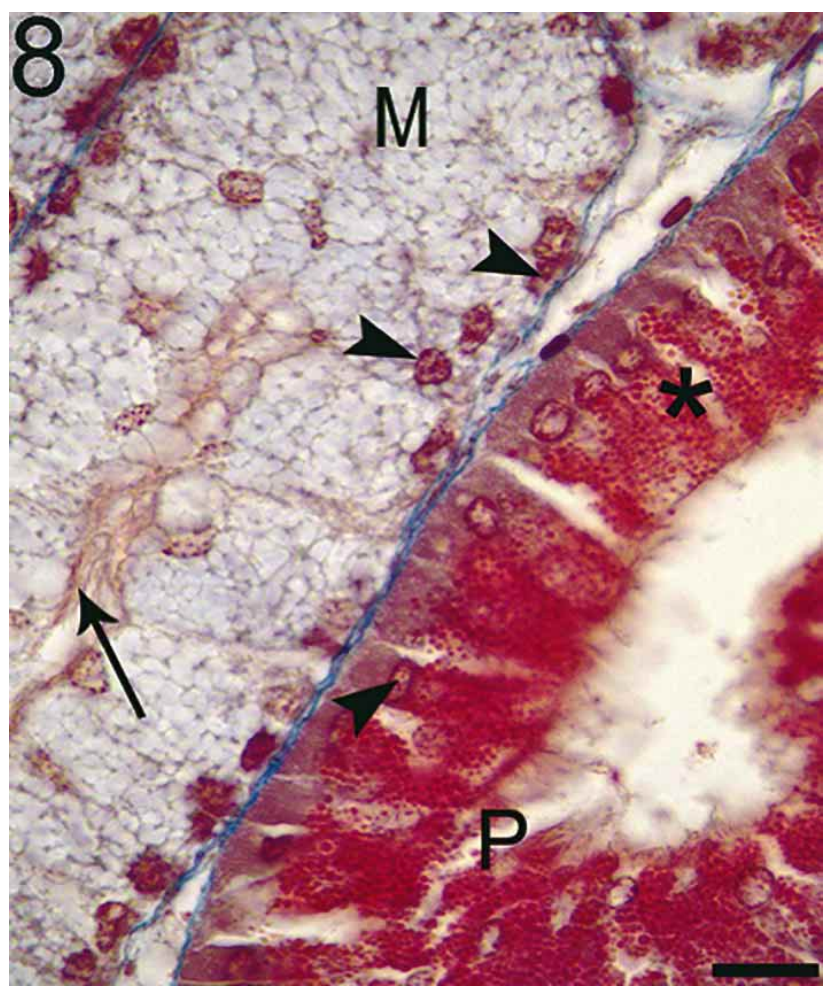

Fig. 8. Oviductal gland. Mucous cranial zone (M) and protein zone (P). Note the cilia of the support cells (arrow) and nuclei of glandular cells (arrow heads); asterisk: protein granulation. Masson's Trichromic stain. Scalebar: $10 \mu \mathrm{m}$.

Table I. Glycosaminoglycans reactivity of the oviductal gland.

\begin{tabular}{llcc}
\hline Zone & Characteristics & AB 2.5 & PAS/AB 2.5 \\
\hline Mucous cranial zone & Simple tubular glands & + & Light fuchsia \\
& Ramified tubular glands. & + & Fuchsia \\
& Simple tubular glands. & ++ & Violet and Fuchsia \\
Protein zone & Simple tubular glands. With spinnerets & - & - \\
Mixed zone & Ramified tubular glands. Duct with mucous cells. & $+++(\mathrm{dc})$ & Light blue (mc) \\
& Adenomers with a mixture of mucous and serous & $++(\mathrm{mc})$ & \\
& cells. & $-(\mathrm{sc})$ & \\
\hline
\end{tabular}

$\mathrm{dc}=$ duct cells; $\mathrm{mc}=$ mucous cells; $\mathrm{sc}=$ serous cells. 


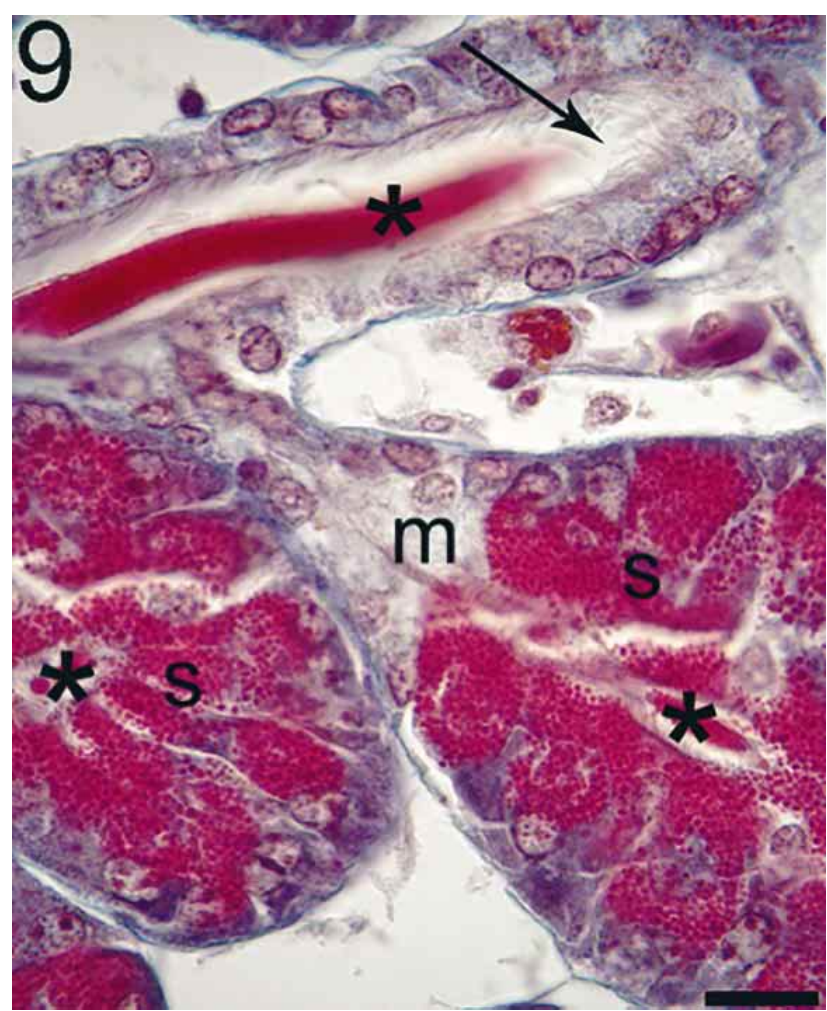

Fig. 9. Oviductal gland. Glands of the mixed zone. Note the secretion in the lumen of the glandular ducts (asterisks) and the cilia (arrow); m: mucous adenomer; s: serous adenomer. Masson's Trichromic stain. Scale bar: $10 \mu \mathrm{m}$.

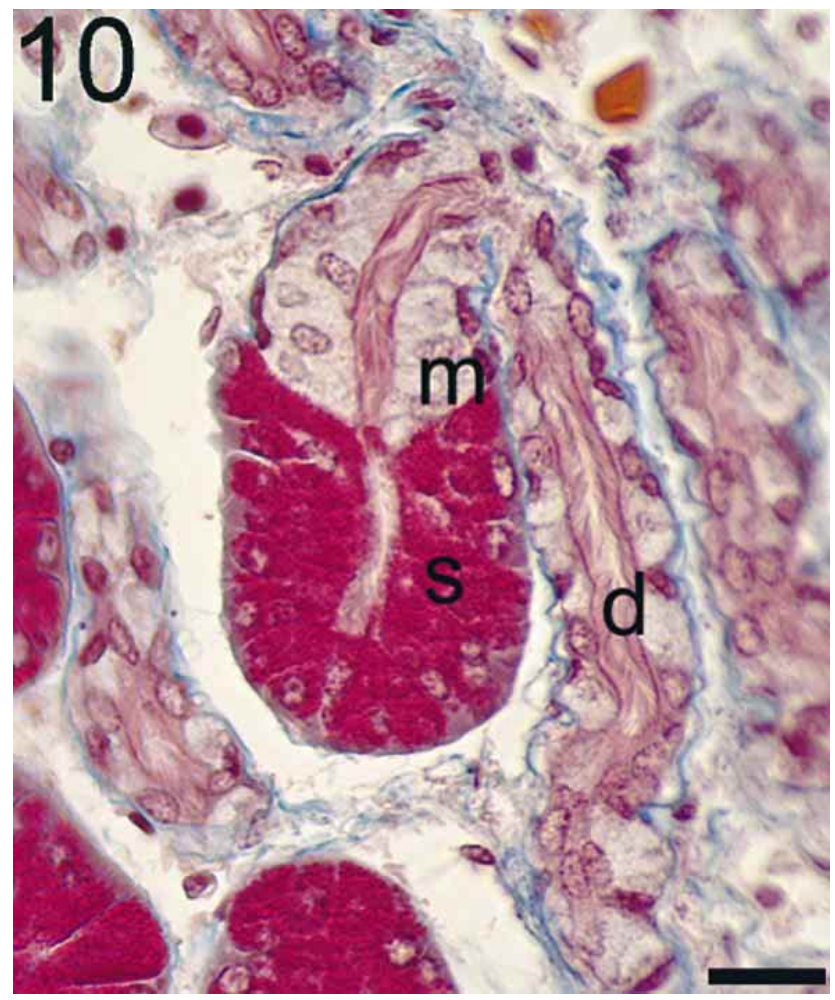

Fig. 10. Oviductal gland. High magnification image of the mixed zone; $\mathrm{d}=$ duct; $\mathrm{m}=$ mucous adenomer; $\mathrm{s}=$ serous adenomer. Masson's Trichromic stain. Scalebar: $10 \mu \mathrm{m}$. differentiate three zones (Figs. 8-10): a cranial mucous zone, a medium protein-producer zone and a mixed caudal zone. The dye affinity of each region is shown in Table I.

Uterus: The uterus of $Z$. chilensis comprises a folded mucosa lined by a simple, basophil, ciliated epithelium and with a highly vascularized chorion (Figs. 11-13). The complexity of the folds increases towards the urogenital sinus with the formation of branched villi whose epithelium flattens (Fig. 13). Epithelial cells show apical granules that react positively to PAS and AB 2.5. The muscular layer arranges in orthogonal sheets. The serosa is formed by a simple squamous or cubic epithelium (Fig. 11).

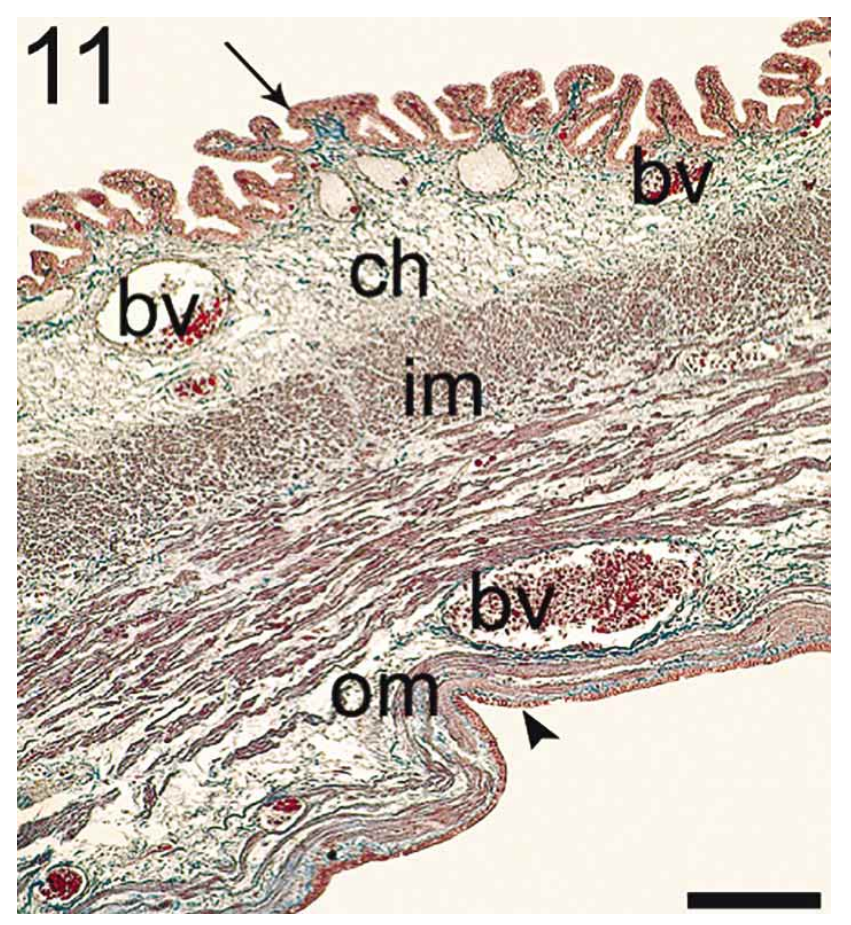

Fig. 11.General view of the longitudinal section of the uterus. Arrow indicates the lining epithelium and arrow head shows the serosa; $\mathrm{bv}=$ blood vessel; $\mathrm{ch}=$ chorion; $\mathrm{im}=$ inner muscular sheet; $\mathrm{om}=$ outer muscular sheet. Scale bar: $150 \mu \mathrm{m}$.

\section{DISCUSSION}

The plan of organization of cartilaginous fish is a highly conserved model throughout more than 400 million years (McEachran \& Dunn, 1998). Within this scheme, the female reproductive tract is relatively similar throughout the group (McMillan, 2007). Zearaja chilensis is not an exception, presenting symmetrical functional ovaries and related organs. 


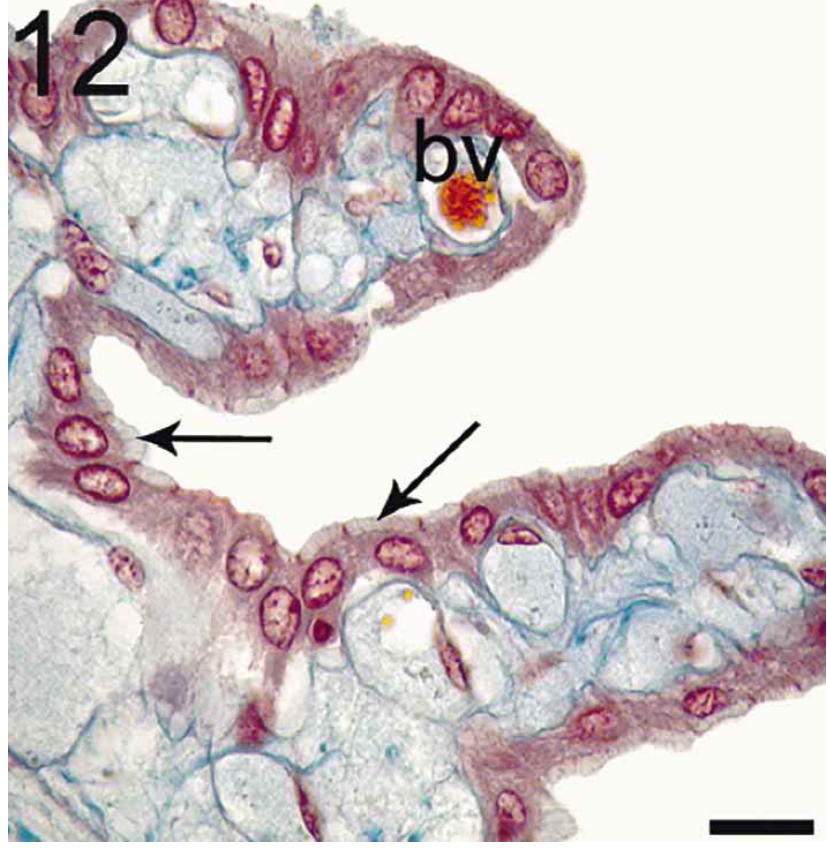

Fig. 12. Uterus. High magnification image of the folded mucosa showing the mucous epithelial surface (arrows); bv= blood vessel. Masson's Trichromic stain. Scale bar: $20 \mu \mathrm{m}$.

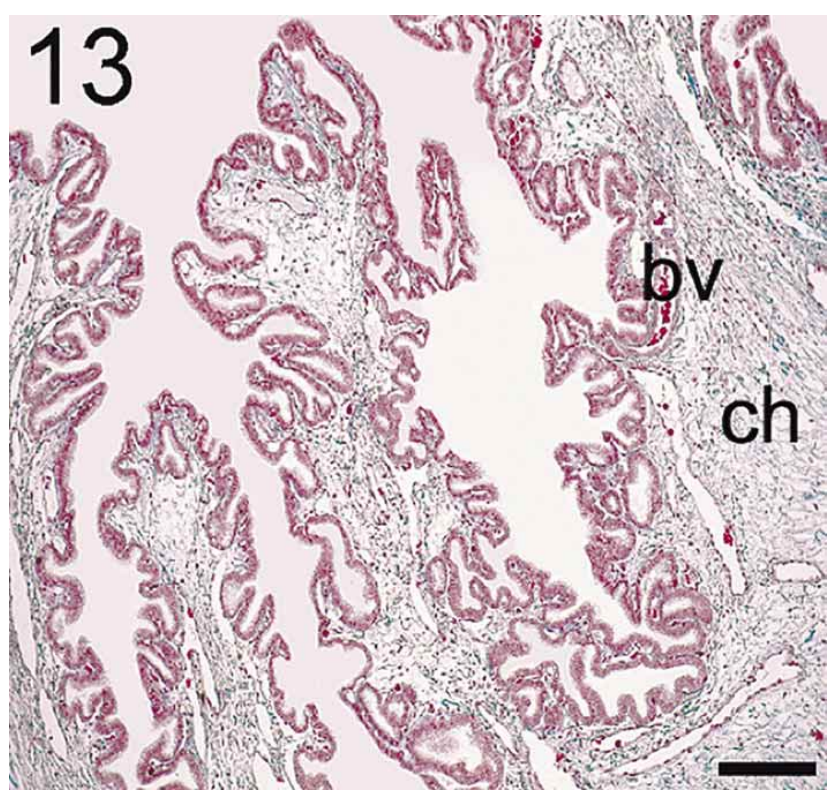

Fig. 13. Uterus. General view of the mucosa showing the branched villi. Note the high vascularization of the chorion; bv= blood vessel; $\mathrm{ch}=$ chorion. Masson's Trichromic stain. Scale bar: $100 \mu \mathrm{m}$.

The organization of the germinative epithelium of $Z$. chilensis seems to be an adaptation that allows distention and has also been recorded in other species (Galíndez et al., 2014). During embryonic development, primordial germ cells originate in the vitelline endoderm and migrate to the germinal ridge, where they begin to multiply and differentiate into oogonia. The presence of oogonia has also been recorded in other Chondrichthyans. In some cases, the presence of these cells has been observed even in exemplars that were close to hatching size (Díaz-Andrade et al. 2009). Likewise, this cell type may be present in maturing females (Díaz-Andrade $e t$ al., 2011; Galíndez et al., 2014). The reproductive potential of species rests, among other things, in the number of primordial germ cells that can be recruited as gametes. So, the presence of oogonia only in the first stages of sexual maturation could be associated to a low reproductive capacity. However, the data here exposed regarding this issue are in a preliminary stage and are presented only for informational purposes. Further studies are being performed to define more accurately the reproductive potential of this species.

The process of development and maturation of the follicles is called foliculogénesis. In Z. chilensis, the follicular epithelium stratifies during this process and once it does, it remains unchanged. This pattern is also observed in other batoids (Prisco et al. 2002). The presence of different follicular cells has also been reported in other Rajids (Díaz Andrade $e t$ al., 2009, 2011; Hamlett et al., 1999; Prisco et al., 2002). Moreover, Prisco et al. (2002) have reported at least three different types of follicular cells in Torpedo marmorata, distinguishable by their ultraestructural features. However, a more profound analysis, at an ultrastructural and cytochemical study, is needed for a more accurate typing of follicular cells in the red skate.

The zona pellucida of most vertebrates is an acellular, thin layer, composed by glycoproteins and produced by both, the follicular cells and the oocyte. In cartilaginous fish, this structure has an atypical dynamic, showing a drastically width increases even just at the beginning of yolk input (Davenport et al. 2011). The onset of the zona pellucida's deposition in $Z$. chilensis starts at the beginning of folliculogenesis, in the primordial follicle. This is not the common pattern, so that in other species this acelular coat deposits at the primary follicle step (Hamlett et al., 1999). The chemical nature of the zona pellucida indicates the presence of neutral glycoproteins and the absence of acid mucins. These behaviors are common to most studied Chondrichthyan and differ from those exhibits for the genus Sympterygia (Díaz-Andrade et al., 2009, 2011).

The relationship between the oocyte and the follicular cells is not only crucial for yolk input but also for their modulation (Hutt \& Albertini, 2007). In Z. chilensis the presence of cellular interactions between both cell types seems clear. However, the material employed for this work was stored in cold chambers for several days, so that structural details may have not been correctly preserved, making difficult an accurate conclusion. 
Like other Chondrichthyans (Prisco et al., 2007), Z. chilensis exhibits a double theca. The connective nature of the inner one and the high vascularization at the beginning of vitellogenesis leads to assume that is involved in the transport of yolk precursors. The outer theca depicts cuboidal secreting cells, probably with a steroidogenic capacity, as it has been recorded in other species (Prisco et al., 2002).

According follicles mature there is an increase in size and structural complexity. The yolk input and accumulation provides sustenance for subsequent embryonic development. In Z. chilensis there is a clear evidence of precursor's translocations by means of granulosa cells, both columnar and globed-shaped cells. This has also been recorded in other species (Prisco et al., 2002; Díaz-Andrade et al., 2009).

Atretic follicles result from the involution of the oocyte and its resorption by phagocytosis, and can be triggered at any stage of follicular development (Hisaw \& Hisaw, 1959). In the red skate, atretic follicles were observed in animals of all maturational stages. The atretia rate is an important parameter for the evaluation of ovarian fecundity in fish, so that more studies are needed in commercially important species, such as Z. chilensis.

Different methods are used to determine the sexual maturity stage in cartilaginous fish. Usually, the criteria are, essentially, macroscopic. In females, the diameter and color of "eggs", the overall appearance of the uterus and oviducal glands and the presence of eggs or embryos are used as indicators (Serra-Pereira et al.; Stehmann, 2002). In Z. chilensis there is a significant difference between the onset of vitellogenesis noticeable at a microscopic level and that seen at naked eye. If we take this into account, it seems clear that considering only macroscopic criteria to evaluate the maturity stage in a fish population could lead to overestimate the size at first sexual maturity and therefore, underestimate the potential of the resource. Although the histological work may seem cumbersome and expensivein a fishery management context, the quality of information provided and the accuracy in the estimation of sexual maturity is invaluable and may contribute to fine-tuning of policies to apply regarding the catches.

Once the oocyte is released from the ovary it is collected by the ostium, passes through the oviduct and arrives to the oviductal gland, which is a conglomerate of tubular glands that secrete the third egg envelopes. The three zones referred in this work correspond with the four fundamental zones reported in the oviductal gland of most elasmobranchs. In the red skate, the mucous-secreting zone corresponds to the club and papillary and the protein-producing zone is homologous to the baffle zone. On the other hand, the terminal zone, with a mixed secretion, matches the same-named zone of other species. In general, the oviductal gland is similar in all studied elasmobranchs, with some few exceptions (Hamlett et al., 1998). Considering that the function of the oviductal gland is to secrete the wrappers that protect the egg, it is clear that yolk sac species are those which exhibit the most complex organization and Z. chilensis is not an exception to this.

The general microscopic organization of the uterus of Z. chilensis agrees with that recorded in other elasmobranchs (Díaz-Andrade et al., 2013; Galíndez et al., 2010). In oviparous species, the uterus houses the egg capsule during its sclerotization and thereafter, until oviposition. The uterus structure in these species is quite simple and leads to the assumption of a secondary role. However, the vascular net located below the lining epithelium indicates that this organ does not serve only as a container, but it fulfils an active role in the process of metabolites exchange between the embryo and the mother, the supply of oxygen necessary for the capsule's sclerotization and in the transport of the capsule through the uterus. This fact has also been recorded in other oviparous species (Díaz-Andrade et al., 2013).

Elasmobranchs possess a life history completely different from bony fish. These features make them more susceptible to environmental disturbances and fishing pressure (Field et al., 2009). Z. chilensis is an important economic resource in Argentina and their fins are highly prized and demanded in the Asian market (Paesch \& Oddone, 2008). The directed fishing that this species has undergone in the last years has exerted an important pressure over the resource, evidenced mainly by the decrease in abundance and in the size at first maturity recorded in the last 20 years (Paesch \& Oddone). All these factors make necessary an integral analysis of the life history of the red skate, before population's decline becomes irreversible.

In the last decades, Elasmobranchs have become the center of discussion in the fisheries community worldwide, so that Argentina, such as other fishing countries, has implemented a National Plan of Action for the Conservation and Management of sharks, rays and chimaeras (PAN - Sharks, Federal Fisheries Council, Res No. 6/2009). This work contributes to its guidelines, increasing the knowledge of a valuable species. In this context, the histological analysis of the reproductive tract, not only allows clarifying the mechanisms governing the reproductive cycles, but also provides significant information for sustainable fisheries management.

ACKNOWLEDGEMENTS. We thank the Fish Plant "Río Salado" for providing us the specimens and the CONDROS Group of IMPAS for your cooperation. Special thanks go to Lic. Carolina Moya for collaborating in the sampling and Dr. María Constanza Díaz Andrade for your collaboration. 
WEHITT, A.; DI GIACOMO, E. E. \& GALÍNDEZ, E. J. El sistema reproductor femenino de Zearaja chilensis (Guichenot, 1848) (Chondrichthyes, Rajidae). Gametogénesis y validación microscópica de los criterios de madurezInt. J. Morphol., 33(1):309-317, 2015.

RESUMEN: Los condrictios son extremadamente susceptibles a la explotación pesquera debido, entre otras cosas, a sus adaptaciones reproductivas. Los conocimientos básicos de sus parámetros reproductivos son esenciales, ya sea desde el punto de vista ecológico como económico. Zearaja chilensis constituye un importante recurso económico en América del Sur. En este trabajo se analiza la anatomía microscópica del sistema reproductor femenino y la talla de inicio de la vitelogénesis. El material se fijó en Bouin y se procesó mediante técnicas histológicas de rutina. Ambos ovarios son igualmente funcionales. La foliculogénesis presenta el mismo patrón de otros condrictios. Los folículos con diferentes grados de maduración coexisten en animales maduros, con la excepción de las oogonias, que sólo se observaron en los individuos inmaduros. Los folículos atrésicos se registraron en todas las etapas de la maduración. La talla de inicio de la vitelogénesis, microscópicamente registrada, es inferior a la detectada en el ojo desnudo. La glándula oviductal y el útero muestran similitud con lo reportado en otros peces cartilaginosos lecitotróficos. Este trabajo describe por primera vez, la microanatomía morfofuncional de la especie y pone a prueba la precisión de los criterios comúnmente empleados para la determinación de la madurez sexual, una información crítica para la determinación de las políticas de gestión.

PALABRAS CLAVE: Elasmobranquios; Sistema reproductor; Ovario; Zearaja chilensis.

\section{REFERENCES}

Alonso-Fernández, A.; Alós, J.; Grau, A.; Domínguez-Petit, R. \& Saborido-Rey, F. The use of histological techniques to study the reproductive biology of the hermaphroditic mediterranean fishes Coris julis, Serranus scriba, and Diplodus annularis. Mar. Coast. Fish. Dyn. Manag. Ecosyst. Sci., 3(1):145-59, 2011.

Davenport, I. R.; Weaver, A. L. \& Wourms, J. P. A novel set of structures within the elasmobranch, ovarian follicle. $J$. Morphol., 272(5):557-65, 2011.

Díaz-Andrade, M. C.; Galíndez, E. \& Estecondo, S. The ovary of the bignose fanskate Sympterygia acuta Garman, 1877 (Chondrichthyes, Rajidae) in the Bahía Blanca estuary, Argentina: morphology and reproductive features. Braz. J. Biol., 69(2):405-13, 2009.

Díaz Andrade, M. C.; Galíndez, E. J.; López-Cazorla, A. \& Estecondo, S. Ovarian Folliculogenesis in the Smallnose Fanskate Sympterygia bonapartii (Müller \&Henle, 1841) (Chondrichthyes, Rajidae). Int. J. Morphol., 29(1):174-81, 2011.

Díaz-Andrade, M. C.; Lopez-Cazorla, A. \& Galíndez, E. J. Histological Remarks of the Uterus of Sympterygia acuta (Garman, 1877) and Sympterygia bonapartii (Müller \&Henle, 1841) (Chondrichthyes; Rajidae). Int. J. Morphol., 31(3):86472, 2013.

Dulvy, N. K. \& Reynolds, J. D. Predicting extinction vulnerability in skates. Conserv. Biol., 16(2):440-50, 2002.

Dulvy, N. K.; Baum, J. K.; Clarke, S.; Compagno, L. J. V.; Cortés, E.; Domingo, A.; Fordham, S.; Fowler, S.; Francis, M. P.; Gibson, C.; Martínez, J.; Musick, J. A.; Soldo, A.; Stevens, J. D. \& Valenti, S. You can swim but you can't hide: the global status and conservation of oceanic pelagic sharks and rays. Aquat. Conserv. Mar. Freshw. Ecosyst., 18(5):459-82, 2008.

Field, I. C.; Meekan, M. G.; Buckworth, R. C. \& Bradshaw, C. J. Chapter 4. Susceptibility of sharks, rays and chimaeras to global extinction. Adv. Mar. Biol., 56:275-363, 2009.

Galíndez, E. J.; Díaz Andrade, M. C.; Moya, A. C. \& Estecondo, S. Morphological Changes in the Pregnant Uterus of the Smooth Hound Dogfish Mustelus schmitti Springer, 1939 (Gatuzo) (Chondrichthyes, Triakidae). Microscopic Study and Phylogenetic Reproductive Implications. Int. J. Morphol., 28(4):1003-10, 2010.

Galíndez, E. J.; Díaz Andrade, M. C. \& Estecondo, S. Morphological indicators of initial reproductive commitment in Mustelus schmitti (Springer, 1939) (Chondrichthyes, Triakidae): folliculogenesis and ovarian structure along their life cycle. Braz. J. Biol., 74(3):S154-63, 2014.

Hamlett, W. C.; Knight, D. P.; Koob, T. J.; Jezior, M.; Luong, T.; Rozycki, T.; Brunette, N. \& Hysell, M. K. Survey of oviducal gland structure and function in elasmobranchs. J. Exp. Zool., 282(4-5):399-420, 1998.

Hamlett, W. C.; Jezior, M. \& Spieler, R. Ultrastructural analysis of folliculogenesis in the ovary of the yellow spotted stingray, Urolophus jamaicensis. Ann. Anat., 181(2):159-72, 1999.

Hisaw, F. L. Jr. \& Hisaw, F. L. Corpora lutea of elasmobranch fishes. Anat. Rec., 135:269-77, 1959.

Hutt, K. J. \& Albertini, D. F. An oocentric view of folliculogenesis and embryogenesis. Reprod. Biomed. Online, 14(6):758-64, 2007. 
WEHITT, A.; DI GIACOMO, E. E. \& GALÍNDEZ, E. J. The female reproductive system of Zearaja chilensis (Guichenot, 1848) (Chondrichthyes, Rajidae). Gametogenesis and microscopic validation of maturity criteria. Int. J. Morphol., 33(1):309-317, 2015.

Kyne, P. M. \& Simpfendorfer, C. A. A collation and summarization of available data on deepwater Chondrichthyans: Biodiversity, life history and fisheries. Queensland, I.U.C.N. S.S.C. Shark Specialist Group for the Marine Conservation Biology Institute, 2007.

Massa, A. M. \& Hozbor, N. M. Evolución de las estimaciones de abundancia de los peces cartilaginosos demersales de mayor valor comercial del atlántico sudoccidental, capturados entre $34^{\circ}$ y $41^{\circ} \mathrm{S}$ a profundidades menores a $50 \mathrm{~m}$. In: Wöhler, O. C.; Cedrola, P. \& Cousseau, M. B. (Eds.). Contribuciones sobre biología, pesca y comercialización de tiburones en la Argentina. Aportes para la elaboración del Plan de Acción Nacional. Buenos Aires, Consejo Federal Pesquero, 2011. pp.193-205.

McEachran, J. D. \& Dunn, K. A. Phylogenetic analysis of skates, a morphologically conservative clade of elasmobranchs (Chondrichthyes: Rajidae). Copeia, 1998(2):271-90, 1998.

McMillan, D. B. Fish Histology: Female Reproductive System. Dordrecht, Springer, 2007.

Musick, J. A. \& Ellis, J. K. Reproductive Evolution of Chondrichthyans. In: Hamlett, W. C. (Ed.). Reproductive Biology and Phylogeny of Chondrichthyes: Sharks, batoid and chimaeras. Enfield, Science Publishers Inc., 2005. pp.45-79.

Paesch, L. \& Oddone, M. C. Change in size-at-maturity of the yellownose skate Dipturus chilensis (Guichenot, 1848) (Elasmobranchii: Rajidae) in the SW Atlantic. Neotrop. Ichthyol., 6(2):223-30, 2008.

Prisco, M.; Loredana, R. \& Piero, A. Ultrastructural studies on developing follicles of the spotted ray Torpedo marmorata. Mol. Reprod. Dev., 61(1):78-86, 2002.

Prisco, M.; Liguoro, A.; Ricchiari, L.; Del Giudice, G. \& Andreuccetti, P. Oogenesis in the spotted ray Torpedo marmorata. Rev. Fish Biol. Fish., 17(1):1-10, 2007.

Rivera Gómez, M. \& Pettovello, A. Las rayas como fauna acompañante del langostino patagónico Pleoticus muelleri en el Golfo San Jorge. Puerto Madryn, IV Jornada Nacional de Ciencias del Mar, 2000.

Serra-Pereira, B.; Figueiredo, I. \& Serrano Gordo, L. Maturation of the Gonads and Reproductive Tracts of the Thornback Ray Raja clavata, with Comments on the Development of a Standardized Reproductive Terminology for Oviparous Elasmobranchs. Mar. Coast. Fish. Dyn. Manag. Ecosyst. Sci., (3):160-175, 2011.

Stehmann, M. F. W. Proposal of a maturity stages scale for oviparous and viviparous cartilaginous fishes (Pisces, Chondrichthyes). Arch. Fish. Mar. Res., 50(1):23-48, 2002.

\author{
Correspondence to: \\ Anahí Wehitt \\ Laboratorio de Histología Animal \\ Departamento de Biología \\ Bioquímica y Farmacia \\ Universidad Nacional del Sur \\ San Juan 670 \\ Bahía Blanca, 8000 \\ Buenos Aires \\ ARGENTINA
}

Email: anahiwehitt@gmail.com

Received: 28-08-2014

Accepted: 19-01-2015 